\title{
THE DESIDERATIVE CONSTITUTION: A TENTATIVE OUTLINE OF A THEORY
}

\author{
Ву С. Ево
}

The rationale of this pompous-sounding essay is the unanimous opinion among knowledgeable students of the politics of developing areas that sees them as providing an object lesson in the existences of incongruence between the formal and the effective norms of the political order - a wide divergence between norms stipulated for the official framework of governance and those actualized in behaviour. These scholars concur in discerning the political arena of these societies as literally the cockpit of confrontation between complexes of institutions and values that are carbon-copies of those found in the industrialized countries of the West, and those of inherited or indigenous stock. The general tide of this encounter, these scholars aver, tends to favour the latter, so that they over-ride the foreign transplants and enjoy the balance of advantage in defining political behaviour. Because of this systemic imbalance, a distinctive aspect of political life in these countries is a chasm that seemingly separates the world of theory from the world of practice, the sphere of "law-in-books" from the sphere of "law-in-action". Put in another way, our scholars contend that beneath the shows of things and, to a striking degree, conditioning the workings of the mint-new facade of loan-institutions, there thrives a powerful undertow of non-modern norms and values. And because in any respects the interaction between these two institutional complexes tends toward mutual interference and incoherence, their juxtaposition inevitably provokes more or less acute and chronic tensions, which in their turn, breed prennial crises of survival in the political systems of the emergent countries ${ }^{1}$.

\section{The Nigerian Experience}

The experience of the transplanted parliamentary institutions in Nigeria in the period between 1960 and 1967, for instance, lends credence to this line of reasoning. During this decade, Nigeria tried courageously but inauspiciously to pull off the miracle of containing new wine of imported structures and values in practically speaking, old bottle of indigenous contexts. Throughout the period in question, the sharp strains and stresses within the "cultural mix" of the two tendencies and arising from their mutual hostility and incongruity left the issue trembling in the balance, until the accumulated weight of tensions became unsustainable and flamed up into a catastrophe that put paid to the bizzare venture. With the help of the many recent analytical lights thrown by objective scholars on political happenings in the emergent countries, one can sum up the lesson of the Nigerian debacle as a grim admonition of the woe that betides any society that, in experimenting with a polity that seeks to intercross modern and primordial types, fails to provide

\footnotetext{
1 For scholarly, though stylistically rugged, exposition of the various dimensions of this divergence and some highlights of its effects in developing societies, see the extensive works of Fred W. Riggs, especially, Administration in Developing Countries (Boston: 1964).
} 
adequate measures designed to counter-balance the preponderant weight of the durable legacies of tradition, whose innate character bestow upon their activities seemingly inexorable tendencies to generate consequences inimical to the evolution and growth of modernising institutions and norms. Developing nations, the vital lesson appears to be, are likely to find that their road to a smooth and orderly form of political development is largely paved by a strategy that aims at bringing about a viable state of equilibrium between the two cultural strands they are hoping to synthesize, overtime, into a coherent amalgam that can withstand the test of storms and stresses. This implies that while they are about the business of finding the road to their ultimate goal of systemic eunomia, it behooves them, if they wish to stave off calamity in the process, to cast about for plausible means to curb and contain the existing preponderance in their social systems of some of the major configurations weaving and woven by primordialism. Expressed in professional jargon they face the ticklish task of devising effective weapons for influencing the alchemy of the melting-pot wrought in traditional society by the agency of culturecontact a process synonymous with that of "incorporative dualism" and expressing the developmental sequence now occupied by most of the developing countries - so that it will increasingly evolve without perenial threats of incipient fiasco, in the direction of "fusional" dualism, partly by means of the catalyst of formal measures intended to foster the upsurge of the attributes of modernity and the emasculation and eclipse of the harmful traces of old leaven ${ }^{2}$.

\section{Functions of the Constitutional Framework}

The facilitation of the transition of the Nigerian political system from its present unhealthy basis in which it continually reels from crises to worse crises to more confident foundation, it would seem, poses us the challenge to rack our brains and come forward with a credible plan for steering it away from its agonised and agonising course. Personally, I consider it not entirely whimsical to suggest that a cardinal option open to us is structural in origin and nature and concerns the type of constitutional frame to be devised for the system of the post-military Second Republic. Viewed, perhaps not entirely unjustly, in some quarters as a barren and lifeless collection of legal machinery because lacking the vitalizing sap of supportive social institutions and conventions, structural-legal fabrics can of ten play a valuable

\footnotetext{
2 The basis of this argument is owed to a broad agreement with the perceptive proposition of systems, or systems in which cultural change is taking place". This represents a postulation of the universality of cultural dualism. Almond goes on to distinguish and characterize differing epitomes of stages of acculturation and change. "Fusional dualism" represents the modern form and featuring "a homogenous political culture, secular and traditional in content" and signalized by "a penetration and domestication of the informal (traditional) by the formal (modern). "Isolative dualism" is distinguished by the fact that "Traditionality and modernity are not uniformly distributed but are concentrated in different parts of the cultural entity. Its seal is the fact that "the traditional areas would manifest the kind of dualism we attributed to non-Western societies... while the other would manifest the kind of dualism we attributed to non-Western societies ... while the other
components would manifest the modern form of dualism". The "incorporative pattern is not a fused complex, "the modern and pre-modern elements have not combined, or fused, and at the same time they are not sharply antagonistic. The two systems exist side by side, the acculturative process continues and the outcome may turn out to be fusional or isolative, depending on events." In characterizing the nature of incorporative dualism, he sees the experience of a modern organ of government (e. g. Parliament) operating in this cultural setting as illustrative, and proclaims that the dualism of the non-Western parliament may really amount to a subversion of the formal (modern) by the informal (traditional). Thus, one is justified in judging from Almonds classificatory criteria that, generally speaking, "fusional dualism" is one in which the modern cultural configuration wields the directive power over ensuing behaviour while the "incorporative dualism" denotes the stage at which the traditional configuration is determinative of the shape of actualities.
} 
role in shaping and moulding human behaviour and in constraining the perimeter of its aberrant expressions. This view, as it has been persuasively put by one of the leading lights in the field, stresses that the formal structure of government provides the framework within which the extra-governmental groups conduct their conflicts and constitutes the principal agency for stating authoritatively who gets what, when, and how. A further highlight of this view is the notion that "the rules to some extent make the game, and provide the informal processes with limits within which they must operate ${ }^{3}$ ". But no matter how reassuring this understanding may sound to those who have hitched their hopes to the star of formal structures to work the magical riddance of the polity of its malady, yet without getting a clear and unambiguous handle of the pre-requisites for the all-important objective, these optimists are bound sooner than later to realize that they have been living in a fool's paradise. This is the equivalence of warning that it is one thing to settle for a constitutional tack to the problem of relieving the polity of its invertebrate malaise, for this merely announces the beginning of the battle. Another thing that is far tougher and of far more crucial importance concerns the hard choice that must be made as to the type of scheme that is best fitted for the purpose of helping us to surmount the most besetting sins of our socio-political existence that play a big role in stultifying our aspirations for the attainment under optimum conditions of the era of "fusional dualism".

This vital task strikes me as one that firmly rules out any recourse to idealism. By this I am referring specifically to that perspective of institution-building that leads to attempts to embody, simpliciter, in formal structures some grandiose but vague platitudes and doctrines without any thought of their relativity to the specific parametric matrix of the target society; that is to say, without weighing the factor of their workability, which in turn, is, a function of degree of "fit" between these glib universals and the objective conditions in which the particular polity is imbedded. This skepticism must also apply to the procedure that may be labelled the "nomethetic", which postulates certain structural and ideological categories as the epitome of wise statecraft, so that, were we to embrace it, we would be tempted with almost procrustean rigors and slavishness, to mould our own constitutional pattern out of these supposedly ubiquitions criteria. Were we to be lured into adopting anyone of these dubious nostrums, we would be committing a grievous blunder that is a tailor-made for the unacceptable fact of institutionalizing the recurring decimals of systemic disorder in the polity, not to mention that of making a virtue of the vice of anachronism in state-building. What a fruitful performance of our task seems to call for is a wholehearted commitment to a thorough-going empiricism of the type that would enjoin upon us the paramount duty of first obtaining a high-fidelity picture of the existent politico-cultural context - an ideographic model - that reliably mirrors the dynamic collocations of societal forces. Having once obtained this snapshot, it will become our opportunity and duty to scan it into its constituent black and white elements, and then proceed to discriminate those aspects we consider wholesome enough to foster, from those we deem to be part and parcel of the syn-

\footnotetext{
3 Austin Ranney, The Governing of Men. p. 394

Ranney belongs to the school of thought that pre-empts the golden mean between the traditionalist who over-emphasize the importance of formal structure, and the Empirical or behavioural school which exalts the primacy of the informal or psycho-social forces. For a learned exposition of the latter's gospel, see David Easton, The Political System (1960).
} 
drome of the societal malady, part of the answer to which, as already suggested, it is legitimate to seek in the form and substance of a set of well-conceived legalstructural components.

The basic logic of the structural therapeutics adopted here follows the profound insights crystallized in the 18 th century by Montesquieu. Declaring in his celebrated work, "The spirit of the laws" that the law "is the necessary relations arising from the nature of things", he implies that a form of government, construed in its broadest sense, is a whole requiring the mutual adjustment of all a people's institutions, if the government is to remain stable and orderly. He urges the view that the code of formal laws and other institutional complexes of a society must always be symmetrical or congruent with its infra-structure of phenomenal realities. So far, so good. But our present purpose obliges us to regard Montesquieu's axiom as a point of departure for further refinement. For the name of the game is not for us to replicate in order to reinforce in and through legal structures all the prevalent forces in our society; on the contrary, we are absolutely in need of countering those sources with pernicious tendencies. In other words, the goal is not to secure a symmetrical order of relationship between political structure and culture; rather, we need to contrive a mutual relationship between them characterized by the pattern of dissymmetry that exists between the two human hands or between positive and negative pictures of an object. For if we once realize in our legal institutions a dissymmetrical print of some of the more intractable of our behavioural orientations, we will have succeeded in devising a system, that prima-facie as well as actually, reflects our felt needs and requirements, and highly capable of going a long way to satisfy them, as well. This is so inasmuch as the operation on such a legal order will, in practice, tend to oppose and choke off the vigorous play of the unwanted traditional influences, thus strengthening the hand of those elements deemed to be among the desiderata in our touch-and-go race against time for the achievement of the state of "fusional dualism", where the modern forces, in the felicitious phrase of Almond, will penetrate and domesticate the intransigent elements of primordialism. This sort of constitution I have chosen to label the "Desiderative Constitution". It may be defind as a "scheme of governace that lays the foundations for the take-off of the polity into a period of sustained, stable development by constraining and taming through formal structures the dysfunctional operation of traditionalism while retaining deep roots in, and reinforcing, its wholesome manifestations".

\section{The "Desiderative Constitution"}

The strategy elaborated here utilizes recent insights developed by developmental scholarship, and conceptualizes the goal of nation-building - here equated with the increasing emergence of those qualities popularly associated with "fusional dualism" - as a continuum whose major inter-grades are viewed as epochs of state-institution-building, a function symbolized here by the "Desiderative Consti-

4 George H. Sabine, A History of Political Theory; 1961, p. 553 
tution", from the turbulent state of "incorporative dualism ${ }^{5}$ ". But this poignantly tantalizing quest of fusional dualism or consolidated nationhood can be expressed in a programmatic form that fulfills the purpose of spotlighting those tell-tale signs whose increasing frequency will be held to presage genuine gains in the desperate battle to reach the goal of "fusional dualism". A handy version was formulated in 1970 by the Head of the Federal Military Government as the attainment of a united, strong and self-reliant nation; a great and dynamic society; a just and egalitarian society; a land of full and equal opportunities for all its citizens: a free and democratic society ${ }^{6}$. Our next and cardinal duty is to identify and underline the roots of some of those acknowledgedly pernicious attributes of the social milieu whose operations generate the major forces that tend to make havoc of our efforts to achieve a form of polity with the major earmarks delineated by the Head of State. For it is precisely the devilment wrought by such societal forces that we have undertaken to uncover worthy ways of checking and abeting in and through the counterveiling mechanism of a desiderative constitution. We will now proceed to map the blueprint of the paradigmatic structure of such a constitutional dispensation. In the sequel, the major component concepts and structures of the Desiderative Constitution will come to light. Destined to be yielded by this elaboration will also be its decidedly heuristic methodological value.

\section{Centrifugal Forces}

An unmistakable attribute of the Nigerian society is its appearance as a kaleidoscope of traditional groups or communities classifiable into three major dimensions or foci. These are the foci of kinship groups or primary identification, traditional political groups or historical identification, and cultural groups or cultural identification ${ }^{7}$. This intricate grid of diversities, abstractly considered, has an enormous aesthetic value, as do most gorgeous handiworks of nature. But beneath this colourful exterior, there lurks an enormous potential for mischiefmaking, especially if the more volatile and explosive parameters inherent in this complex pluralism are not approached with adequate circumspection and vision. For, experiencially speaking, the legacies of pluralism have always been known to exercise an insidious sway in many unsuspected quarters in developing societies like our own, so much as that otherwise progressive and liberal minds often succumb willy-nilly to their primordial allure and evince parochial and retrograde

\footnotetext{
$5 \mathrm{C}$. H. Dodd has summarized some of the problems of crises of modernization as listed by the various authors: "the problem of legitimacy might be expressed as a problem of state-building ... the crises of identity as the problem of nation-building "see his Political Development (1972); p. 13. In a latter part of this work, he discusses the various orders of sequence or precedence postulated by these writers for the modernization variables of authority (state-building), unity (nation-building) and equality (participation) as "unity-authority-equality, and "authority, identity-equality". He cites Huntington's belief in the superiority of the latter progression because "the longer political institutions exist the more flexible they become and in consequence better able to lead and moderate movement towards national unity and popular participation". This seems to concur with the line being articulated by the present writer that a well conceived and balanced institutional order is capable of escalating our realization of national identity.

6 Broadcast by His Excellency, Major General Yakubu Gowon, Head of the Federal Military Government, Commander-in-Chief of the Armed Forces, 1st October, 1970. Among the major steps he announced as designed to pave the way to these lofty aspirations are: eradication of corruption in our national life, the settlement of the question of the creation of more States, the organization of genuinely national political parties.

7 K.W.I. Post and Michael Vickers, Structure and Conflict in Nigeria, 1960-1965 (1973), p. 27
} 
patterns of attitudes and behaviour. This generalization is apt for all strata and groups in the social structure, for all of whom, at any critical juncture, they are as likely as not to define their perception of the ultima ratio of choice and action. Probing behind this cancerous pluralistic phenomenon, it is easy to identify it as a form of spiral or vortex whose gravitational force decreases in magnitude with increase in distance from the radial center. For the individual, therefore, his proximal loyalties and identifications are invariably, of first and foremost importance and superior to his remote attachment. This means that by and large, at a pinch, in moments that evoke deep-seated instincts and responses, the individual's reflex as well as conscious manifestations will be found to reflect a graded structure of orientations ranging in a descending scale of importance from family to clan to tribe and to nation. In the parlance of social psychologists and sociologists, the heritage of primordialism has bequeathed to us the worrisome proclivity to manifest particularist norms and standards more often than we do those of universalism.

These considerations will inform some of the major ideas and objectives of the Desiderative Constitution. One of its bedrock doctrines is that of federalism, intended, as far as possible, to assure the various ethnic/linguistic entities the right to preserve their own identities and to manage their more private affairs as seems fit and expedient in their sight and judgment. But the federal idea has had a chequered career in this country and each of its leading exponent has tended to give it a symbolic significance and a content that are consonant with his own vision of the basic constitutional role it should play and the needs it should meet in the polity. At the heart of these distinctions has been disagreements, over the degree of authonomy to be accorded to the units vis-a-vis the national government, the level of the federating units, as well as their numbers. Some theorists, like Zik, started out by specifying for a "confederation" of "twenty-four provinces" ${ }^{8}$, whose powers and functions would be conferred upon them by the laws of the confederation. The national government would thus exercise an unchallengeable hegemony over the component units.

Zik's concept of federalism, which Awolowo once dubbed "quasifederal9" was inspired by a conviction that the units of the Nigerian conglomeration deserved he homage of autonomy, but with a scope and value restricted mainly to cultural and local jurisdictions, and not allowed wider territorial or political import. But despite this lowkey legal voice of the provinces (the name he actually called them), they were still expected to play what was considered a highly crucial function of being the electoral constituencies from which the members of the national legislature would be chosen in such a way that it would closely reflect a cross-section of the society's linguistic-cultural make-up. Later on, he toned down his conception of federalism and formulated a project that toed more orthodox lines. Now styling the units as states, they were to number eight and would be credited with expanded authonomy enabling each of them to be "free to develop its own customs but fully conscious of the common bond that binds the whole entity and equally participates in the general legislative machinery ${ }^{\mathbf{1 0}}$."

8 Nnamdi Azikiwe, "Political Blueprint of Nigeria", West African Pilot. March 31 - April $30,1943$.

9 Obafemi Awolowo, Awo: The Autobiography of Chief Obafemi Awolowo (1960), 167.

10 See the "Freedom Charter" of the NCNC; West African Pilot. April 30, 1948. In 1948, Zik raised the number of "States" to 10 based on the main ethnic and/or linguistic lines, to enable each 
The evolution of Obafemi Awolowo's idea on the subject proves to be even more chequered than Zik's. Launching out as a staunch standard-bearer of strict regionalism, whereby Nigeria would be carved into three units, each clothed with far-reaching authonomy and capable of overawing the central authority he began to modify his views and to yield a great deal of ground on many conspicuous fronts. These second thoughts were destined to culminate in the constitutional plan sketched in his "People's Republic" wherein he advocates a federation of 18 linguistic unit-entities. A basic inspiration for this plan was the belief that it would help to solve the minorities' question. Moreover, he now espouses the doctrine that claims the almost inviolable right of the States to autonomy and selfsufficiency in strikingly extensive areas, including their exclusive ownership of residual powers, a prereogative which he had earlier on vindicated on behalf of the regions ${ }^{11}$. Another and the latest of the historic schools of federalism is the basis of the current constitutional system of the country. Decreed into being in 1967, it boasts a twelve-state structure whose territories have been demarcated on a complex basis, including ethnic, linguistic and cultural affinity, historical association, geographical contiguity, absolute and relative viability ${ }^{12}$. Though in theory the states retain very much the same degree of independence from the centre which their immediate predecessors - the regions - enjoyed in the era that ended with the military take-over in 1966, the overshadowing reality that they operate under a military regime, with its unique tradition of strict hierarchical command, does not permit a meaningful comparison between the fortunes of the States ruled by the Federal Military Government and their predecessors the regions - governed under civilian auspices.

Albeit, the smug belief that federalism can contribute to the stability and progress of the country by allaying the fears of ethnic minorities does not appear to have the weight of empirical evidence behind it. The unpalatable truth is that, as many people have repeatedly noted, it does not seem that the minorities' question can ever be finally defused until we federate down at the level of the traditional political groups, that is to say, at the level of the clan or may be lower still, which would oblige us to contemplate the preposterous event of the existence of hundreds of unit-entities. Besides the recent trend of disquieting happenings is an omen that the act of sowing the wind represented by creating more states, will likely reap the whirlwind of intesification of sentiments of ethnic chauvinism and sullen insularity, thus exacerbating the problem of national cohesion and identity against which, paradoxically, federalism is touted as a promising source of specific innoculation.

Consequently, the framework of the Desiderative Constitution, while making room for the federal idea, to be incarnated in the existence of state-entities enjoying adequate legal autonomy, will not pretend that it constitutes the royal road to the resolution of problem passed by the legacy of ethnic pluralism. For one aspect of this subject which often escapes the amount of attention it richly deserves concerns the roots of a minority group's fear of domination and submergence of their rights and interests on the part of ethnic majorities. Due

group exercise local and cultural autonomy within its territorial jurisdiction. See Nigerian Legislative Council Report of the Select Committee of the Legislative Council Meeting at Enugu, with two minority reports (1950), pp. 5-7. See also Nnamdi Azikiwe, Selected Speeches; p. 108.

11 See Obafemi Awolowo, Path to Nigerian Freedom; Thought on Nigerian Constitution: The People's Republic, and the strategy and tactics of the Peoples Republic of Nigeria.

12 Federal Republic of Nigeria: National Youth Corps: Lectures for the orientation course, M.O.P. 162. 
reflection will readily show that minority suspicions and apprehensions stem from one of the enduring vestiges of our traditional part, which I have elsewhere characterized as an innate proneness to manifest particularist attitudes. Everybody, members of minority and majority alike, is acutely alive to, and vulnerable on the score of this our universal failing. This fact helps to feed the standing expectation and belief held by minorities that they will not receive fair and equitable treatment at the hands of majority groups in the allocation of available benefits and opportunities because majority leaders will be irresistibly driven by ingrained parochial leanings to accord preferential treatment to closer ethnic relations than themselves. Federalism, which is contendedly an invaluable instrument for nation-building on the assumption that it is a good sop to the terrible potential passions inherent in the myriad networks of crossing interests and objectives that is among the ubiquitous traits of social pluralism, and that is a balm for the corrosive fears of domination nursed by the minorities is, on historical evidence, a broken reed with a disturbing practice of producing boomerang effects. The seamy side of federalism is that it is notiriously susceptibel to the vice of ethnic/linguistic micro-nationalism and xenophobia, and, consequently, can easily degenerate into a centrifugal force that panders to the corrupt and corruptive passions of primodialism. To counteract this federalism's other face, and mitigate the apprehensions of minorities, withal, the Desiderative Constitution will seek to temper the strict implementation of the conventional idea of federalism with certain bold measures calculated, hopefully, to revolutionize the complacency and inertia that yet characterize thoughts in this area by adumbrating the seminal role that intelligent institutionalization of adequate structures and processes of rural government and rural animation is destined to play in the context of nation-building. One relatively modest innovation, as the foregoing statement clearly foreshadows, calls for a considerable strengthening of self-government at the level of the primary and traditional groupings. Anticipating this demand, Awolowo proposed that "The State legislature or government should not have power to suspend or dissolve a local government council in any circumstance, during the council's statutory term of office ${ }^{13}$." But this does not appear to be as forthright and invincible a guarantee as we would wish. The Desiderative Constitution envisages that a "Charter of Privileges and Immunities" for organs of local government at the primary and traditional strata will be incorporated as a sacrosanct principle of its governmental structure.

\section{National Identification}

But all this is but one major prong of a dual-purpose weapon that can conveniently be labelled as the "Rural Strategy", and partly designed to dissipate the radical fears and misgivings expressed by ethnic minorities.

The other prong of the Rural Strategy, more emotive and contendious is calculated to fight the centrifugal pull which is, admittedly, a universal concomitant of attempts to experiment with federal forms, in societies with notoriously low threshold of ethnic outbursts and disturbances, is to impenetrate the rural/

13 Awolowo, The Strategy and Tactics of the People's Republic of Nigeria, p. 71. 
primordial core concrete symbols that will help to throw the visibility of Federal Government and its activities into high relief for the rural folk. Thus will the rural folk receive the welcome opportunity to become more and more conscious of their other wider sympathies and identifications. It is expected that this widening horizon of experience will trigger a mental catalysis that will spur them into making an escalating level of manifestations of super-tribal attitudes and behaviours. Implementation of this strategy will necessitate a basic requirement that the field of Local Government should become a concurrent subject to both the National and State governments, thus introducing, what amounts to a radical and pungent landmark in the history of Independent Nigeria, the principle that sees no sacredness in the tradition under which the relationship between National organs and local authorities must continue to be mediated, and dissipated, through the layer of State authorities. The Federal government, in other words, should, as a legal as well as a moral obligation, be fully competent to initiate, fund and supervise such local services and projects as it sees fit, especially in areas vitally affecting the social and economic transformation of rural societies. Of course, this does not rule out joint activities between Federal and State governments in rural areas. In a way, this projection of a fruitful sort of functional co-operation between the centre and rural periphery was foreshadowed by the view credited to Dr. Azikiwe demanding that rural government structures should be vested with the functions of "education, hospitals and maternity homes, police, courts, prisons, roads, recreation, agricultural economics and farm management, etc. but that the operation of these duties should be with the assistance and under the supervision of the national government ${ }^{14}$ ". To facilitate mutual co-operation and effective co-operation of efforts by Federal and State authorities in the discharge of their responsibilities as the joint custodians of the progress of the rural masses, there needs a Local Government Committee made up of federal and state officials which will function as a forum for the planning of broad strategies and goals for common endeavours in this sphere of activity. The National Legislature should also maintain a parallel standing body charged with watch-dog role over the formulation and execution of Federal policies and activities partaining to rural areas.

It is plausible that the bold and unprecedented measure propounded here may redound to our advantage by bolstering the current standstill marking our endeavours to instil the idea of national oneness into the minds of our diverse, remote communities. For implementing the step will mean that, for the first time in the history of Independent Nigeria, the ideology of a national community which, even today, reaches the rural communities as an abstract and strange gibberish, will find in the concrete Federal presence, an indispensable cuttingedge for communicating itself to the imagination of the rural folk. Furthermore, it is not entirely suppositious to argue that the active benefits and improvements which the rural folks see as accruing directly from the activities of national agencies in their midst will eventually awaken in them a more positive cognition of the source and provider of the boons and a quickening affective orientation toward it. Increasing manifestation of these attitudes will be an unmistakable indication of the precious ground won in the crusade to galvanize mobilize and lead the apathetic rural masses to cultivate the desirable level and type of awareness that can be

14 Zik, West African Pilot, April 1, 1943. 
tapped and released in strong tides of national feelings and responses, which, in itself, is a welcome event and an important source of our ability to counteract the formidable impact upon rural minds and loyalties stamped by the narrow, restrictive orientations of their rustic horizon.

\section{Traditional Leaders}

Another concern of Rural Strategy that must be mentioned focusses attention on those traditional leadership structures which have demonstrated genuine potentialities as a force for good in the task of nation-building. Chieftaincies come uppermost in mind in this regard. Because of their manifestly great leverage with the masses in the rural areas, it is felt that, as an institution, they are capable of contributing a crucial part in the building of cohesive national unity. Accordingly, the Desiderative Constitution will accord a proud role to them in its scheme of things. It is envisaged that an organ that may be styled "The House of Concord" will be set up under the Constitution. It should be a numerous body, to the extent necessary for it to contain most of the prominent and influential natural rulers and other traditional elites from all parts of the country. The function of this august body will be to deliberate together on all issues touching inter-group peace and harmony. The dignitaries will be expected to advise the Federal Government, whether on the latter's request or on the former's initiative, whenever the members of the House sense any trends that appear to them to portend inter-group bitterness or conflict. The atmosphere of the House should reflect decorum and dignity and conduce to sincere and candid exchange of views and ideas among the members. Nothing remotely approaching the partisan bitterness, rancour and rivalry that often embroil the atmosphere and proceedings of legislative process dominated by political parties should be permitted to encroach upon and undermine the solemnity of their proceedings. The essential function and value of the House should not be seen as encompassing the arena of conventional politics and its mundane tussel for power; it should rather be viewed on a moral plane in that the natural rulers and traditional elites, are as an institution, expected to incarnate the moral and spiritual genius of the Nigerian ethnic conglomerate as a corporate entity.

\section{Checks on Abuse of Power}

It is universally conceded that in this space age rendered outstanding by the rising expectations of the ordinary people in every land for more and better creature comforts and enhanced lifestyle, governments, particularly those in under-developed lands, need an unusually wide array of authority if they are to be able to harness available and potential human and material resources briskly enough so as to keep pace with the outpouring of popular demands. But piling powers in the hands of governing groups and agencies is one thing, and the way these powers are distributed is quite another and more crucial matter. Generally speaking, countries opt for one or the other of two most customary arrangements. Either they establish a "fused or monistic scheme" or they prefer the mode often 
labelled "Pluralist or Separation of Powers". When governmental powers are fused, one organ or a set of organs represents the primary fount of legal legitimacy; in the case of Pluralism or Separation of Powers, more than one organ embodies the national sovereignty and, offer the prototype model, the polity boasts three separate departments of power. In exercising their delegated jurisdictions, however, all are made to follow the plan whereby the functions of each are to some degree co-ordinated with, and balanced against, those of others. In pondering the question of the shaping and sharing of governing powers, certain factors play a key role in determining the mode or criteria to be woven into the framework of the Desiderative Constitution. In keeping with the technique used up to now in an elaboration of the "how" and "why" of these germinal considerations appears germane.

It is beyond contestation that a salient quality of the Nigerian mentality, especially among the members of elite groups and elite strata, is the wont to betray a diffuse orientation toward the use and abuse of power and authority. As used here, diffuseness indicates that one perceives power as incapable of demarcation within definite boundaries so that once a range of authority is granted, it becomes susceptible of almost endless degrees of manipulation. It can be flexed and warped in any manner and direction according to the impulsive mood and the pressing needs of the power-holder. This type of rabid behaviour may be classified under the concept of "power gluttony", a condition of feeling and believing that power begets power, that power can become a sort of breeder-reactor or a substance that gathers like a snowball. To one so schooled in this morbid outlook, power represents a jurisdiction whose dominant norms are those of opportunism and unpredictability, and a faculty that is like nothing if not a unicellular organism endowed with the capacity for endless proliferation, so that its possessor can turn it to as many uses and abuses in response to the bidding of his whims and caprices. Furthermore this inordinate drive to stretch every inch of power into a mile argues a holistic temperament that finds it difficult to reconcile itself to the fact that power can legitimately be delimited into independent compartments. Some authorities have ascribed this particularly strong penchant of our power elites and office-holders for this form of eccentric habit to the telegenic reach of our traditional origins where the rule of diffuseness of institutional norms, whether viewed from the vantage-point of systems of structure or those of function, allowed a high degree of substitutability and interchangeability of roles, with particular reference to those that are high-ranking in the scale of weight of legitimation and sanction.

Coupled with our diffuse orientation to the nature and use of power, mention must also be made of the frequent tendency among our elites to assume, in power terms, a paternalistic or proprietary pose. One shares paternalistic or proprietary attitudes if he feels and acts as though authority vesting in him by virtue of his public role is an attribute inseparably interwined with his person and not a facility bequeathed to the office which he happens to fill. Appropriation is the mental process or condition of merging together one's personality and one's role so that the role is seen to pale into a phantom and vanish when abstracted from the person of the incumbent or, to state it in a somewhat reverse order, one's personality somewhow becomes voided when it is separated from the role. From power or authority being regarded as a tool designated to facilitate the 
discharge of one's roles or attainment of one's ends, it is transmitted and integrated inextricably with the role or end so that both become an inseparable whole. These aberrations help to seal our behavioural norms as consummatory rather than instrumental in variety ${ }^{\mathbf{1 5}}$.

Because of this power megalomania to which we seem to be irresistibly attracted, the Desiderative Constitution, while recognizing the clear necessity to permit the government access to wide latitudes of powers as a means of achieving the mobilization of all available resources towards a brisk and adequate rate of socioeconomic development, will nevertheless, be extremely wary and careful about the way and manner these powers are divided among the various agencies of government. A strong and energetic regime is not necessarily the same thing as tyranny. But where the cultural climate is favourable, and opportunity offers, the combination of the two factors is enough to make such a regime lapse, suddenly or gradually, into a hateful despotism. Were this allowed to happen, it would encompass a disaster of vast proportions. More would be the pity since it cannot even be rightly supposed that an autocratic regime would be in a better position to promote a more rapid pace of socio-economic development. This note of query gains in plausibility when its reference is a society like our own where people in positions of public trust and authority are fond of making the most of, to echo Bagehot's "mot juste", the "dignified" as opposed to the "efficient" parts of power. To this deep-seated propensity to fall into the temptation of assuming naked and arbitrary exercise of power, we must oppose a commensurate structural counter-weight. One good type of this is present in a Presidential regime with built-in separation and dispersal of powers and functions, and the concomitant doctrine of checks and balances. The structure of Parliamentarism which embodies the idea that all springs of legality are fused in one supreme branch of government does not seem to be a suitable answer to the allimportant problem of combating the wide-spread weakness among the members of elite groups and strata for indulging an untrammeled lust for personalizing and aggrandizing power. Parliamentary institutions, moreover, if they are to grow in healthy and auspicious form without the eternal fear that they will soon find their spirit and essence mangled and twisted to vile caricature, require a cultural environment distinguished by the presence of a strong tradition of intellectual and moral inhibitions animating its political class and constantly constraining them to regard power excesses with deep loathing.

Creating the office of a popularly elected President promises another key advantage. This refers to the contribution it is potentially capable of making towards obviating another type of pitfalls that besiege our efforts to weld a nation out of a polyglot of ethnic/cultural communities. It is clearly defensible to contend that the periodic involvement of the entire nation in the collective drama of the campaign to elect a President might, in course of time, come to constitute for all concerned a useful "memoria technica" of our common sharing in a single destiny. This is so because the office of the President will increasingly tend to become invested with the halo of a focal symbol of identification, and a valuable totem of our membership of a national communality. It is hardly

15 For the distinction and discussion of the pair of patternvariables, instrumental and consummatory, in terms of the relationship between "ends" and "means", see David Apter, The Political Kingdom in Uganda (1967), p. 91. 
necessary to add that such a development will greatly boost the vexed and vexing struggle of the nation to contain and progressively diminish the heavy weight of fissiparous forces spawned by the society's criss-cross primordial allegiances, and thereby achieve a giant leap forward toward the major goal of setting on foot a pervasive and viable movement of feelings of togetherness among the hoi polloi. Apropos the desideratum of erecting adequate formal ramparts against the elite weakness toward extremist power options, we must sound a caveat and a note of suspicion. We are alluding to the concept of Prerogative and its implications for the prospect of development of a liberation order in postmilitary Nigeria. The origin of Prerogative, especially in Britain, dates back to the times of absolute monarchs, in whose persons all legal powers were recognized as vesting. With the rise of representative legislative bodies, some of these ancient powers of royalty were stripped away, some fell into disuse and became absolete, while still new ones were picked up by usage rather than by statute. In gist, Prerogative "denotes powers possessed without having been granted or conferred powers acquired by prescription, confirmed by usage (perhaps also by judicial decision) and accepted or tolerated even after Parliament gained authority to abolish or alter them at pleasure ${ }^{\mathbf{1 6}}$." Or, in the comprehensive brevity of Dicey's formulation, the term connotes "the residue of discretionary or arbitrary authority which at any time is legally left in the hands of the crown ${ }^{17}$."

The core of Prerogative, as set forth in these authentic conceptions, we judge to be alarming enough that there should be no room for doubt as regards our stance on the subject. For, in view of the behavioural propensities in our public figures to go to extremes in power terms, it would be nothing short of foolhardy of us, were we to be tempted to play the giddy goat and proceed to adopt and incorporate this potentially disastrous idea into the basic structure of our system. For this is tantamount to opening the door to irresistible temptation to lead our leaders to indulge in avaricious and wanton usurpation of power. This is precisely why the Desiderative Constitution will be obliged to set a face of flint against the institution and to view action to an it out of hand as an indispensable duty to remove all perceived threats to the fond hopes for a stable and normal regime of liberties. For this purpose, there will be a provision enacting simply but bluntly, that no person or institution shall purport to exercise any power or function not derived directly from a specific grant under the Constitution or a statute, or a reasonable inference from these sources. We consider this precaution as both requisite and wise and in the healthy interest of the vulnerable polity. Because of its inherently elastic and unpredictable character, Prerogative is, potentially, charged with grim possibilities for manipulation and abuse by unprincipled and indisciplined demagogues and would-be usurpers. It will be tantamount to reducing to a hostage to fortune the expectation that change and development will move within a democratic orbit, if we once countenance an offer to trust such an explosively flexible instrument in unaccustomed hands not sufficiently socialized to the sophisticated parameters of self-restraint and chaste standards in dealing with power relationships. And it is clear that this lofty accomplishment will be found in any due degrees only in those societies where wide sections of the ruling strata and

16 Frederick A. Ogg and Harold Zink, Modern foreign Governments (1949), p. 49.

17 A. H. Dicey, Law of the Constitution (9th Ed.), p. 424. 
groups have internalized and regularly feel to the marrow the obligations of genteel values and moral scruples so that they instinctively recoil from flagrant and illegitimate conduct.

\section{Conflict Management}

It hardly needs repetition that our political society is riven by conflicts. Conflict is, of course, a ubiquitous part of human societies, from a simple dyad to large groupings like nations. This universality is due to the fact that the desires and preferences of different people do not complement all the time, and the common resources from which they must gratify these desires are in scarce supply. These points have been underlined by a scholar when he difines conflict as "a struggle over values and claims to scarce status, power and resources, in which the aims of the opponents are to neutralize, injure, or eliminate their rivals 18 ". In modernized polities, the operating values and norms of whose members are often held to typify those attributable to the developmental stage of "fusional dualism", it is to be expected that much of the burden of politically significant conflicts will reflect cleavages with secular dimensions. Conflict representation is consequently dominated by associational interest groups ${ }^{19}$. In the case of countries like ours where the force of segmentary patrimonialism is still alive and decisive for wide strata of the population, it stands to reason that much of the rift over values and claims to status, power and resources will naturally stem from traditional ascriptive interests and goals. This is the explanation for the devil of tribalism and all its work which is widely acknowledged as one of the severest maladies afflicting developing societies, and as the bitterest harvest of their onerous heritage of social heterogeneity. It is also held to account for the fact that non-associational interest groups predominate their arenas of conflict.

The maturity and integration of any polity is, in a most vital sense, a direct function of the willingness and ability of its leadership to face and close with the herculean task of alleviating the clash of the criss-cross pattern of the interests pursued by its diverse groups of citizens. Indeed, for a large number of scholars of note, the structures and processes of adjustment and bargaining through which this co-ordination and moderation is pursued define the pith and marrow of politics. As one of them has articulated it, "Politics is a process of regulation; it permits a community to adapt to changes manifested in interest conflict by adjusting social disputes, thus advancing community viability ${ }^{20}$." And Kaplan, for his part, tells us that regulation is "the process by means of which a system attempts to maintain or preserve its identity over time as it adapts to changing conditions ${ }^{21}$."

In view of the above discussions about the stuff of politics, it is regrettable that our past experience of politics leaves a sour after taste and indicates the need to make vast improvements before our political process should be expected to undertake effectively even the least amount of the function of interest resolution

18 Louis Coser; The Functions of Social Conflict (1950), p. 8.

19 For a developmental model of interest group phenomenon, See Gabriel Almond and James Coleman; The Politics of the Developing Areas (1959), p. 33.

20 Dan Nimo and Thomas Ungs, American Political Patterns: Conflict and Consensus (1967), pp. 12-13.

21 Morton A. Kaplan, System and Process in International Politics (1957), p. 89. 
that is expected of any political system worth its salt. We have thrown a passing glance at the problem now coming into question when we querried the presumption that autocratic rule will necessarily benefit the most cause of rapid socio-economic development in the context of developing societies in connection with which was the insight of Bagehot concerning the "dignified" and "efficient" parts of power. We generalized then that political leadership in this country is notoriously prone to savour the "dignified" while making nothing of the "efficient" parts of power. Lucian Pye has predicated the same characteristic of political leadership in non-Western polities in general when he opines that "The affective or expressive aspect of politics tends to override the problem-solving or public-policy aspect" among their leadership ${ }^{22}$ ".

As matters now stand, we have isolated two interrelated sources of the malaise of our political system as it confronts the function of conflict resolution. One relates to the need to avoid or, at the least, minimize the emergence of certain kinds of conflict, especially those born of primordial contentions: the other to that of active commitment to the resolution or, at least, reduction of those that happen to break through into the political system. We wish now, in keeping with the methodological commitment of this essay, to indicate the logical process underlying our option of the suitable form of structural innovation for the task of lifting the political system onto the high way to effectiveness as a forum for conflict resolution or reduction.

\section{Role of Opposition}

It requires little insight to realize that one of the most worrisome and deadly conflicts which bedevilled the political process in the pre-military era was the struggle for status and power among the leading members of the various elite groups and strata that held centre stage. The competition proved to be so intense and the bitterness so corresive mainly because once one group came into power, it tried to block all normal access to future success for the outs. In the sequel, the latter understandably nursed feelings of deep anguish and mortification at the reality that the legal door to their chances of grasping the levers of power had become literally slammed in their faces, locked and the key thrown away. But being men of restless ambition and indefatigable resources, their thwarted hopes began to see in extra-legal, conspiratorial plotting the promise of a new lease of life and a justifiable road to eventual fulfilment, in view of what they justly regarded as the equally violent and extra-legal chicanery employed by their opponents. A key factor that helps to throw explanatory lights upon the deep desperation of the oppositionists is that the fact of controlling political power in those days was so closely correlated with access to an array of rich plums and gratifications in the shape of the most luxurious and elegant life-style the polity could offer. Viewed in this light, the conclusion is almost irresistible that a smouldering sense of the outrage dealt to their fundamental right to compete freely for turns at commanding the perquisites of power and office helped in no small measure to account for the oppositionists' conscious decision to try the

22 Lucian W. Pye, Politics, Personality, Nation-Building (1962), p. 28 
fortunes of treasonable felony by seeking to oust the ins and seize the helm of affairs by means outside the legitimate rules of the game. However this may be, a reasonable hypothesis suggested by the foregoing analysis of the sad events of that troublous era is that, if the majority that controlled the government of the day had allowed the leaders of the opposition some access to meaningful part in the scheme of things, whether outside or inside of the governmental framework, which afforded ample scope for the exercise of their natural talents and abilities, this most probably, would, have gone a long way in defusing their explosive fury.

So persuaded of the validity of this argument, the Desiderative Constitution will take adequate steps to ensure that public roles that afford ambitious men, whether in or out of government, adequate springboard to influence and leadership status are widely distributed throughout its regime structures and processes. Although a unique and, may be, controversial departure from traditional practice, in these parts, there will be a stipulation in the basic law guaranteeing a responsible and prominent role in the policy-making process to the leaders of the opposition. A supremely impertant example of the practical implications of this innovation points to the Leader of the Opposition and his associates. Their offices, salaries, privileges and other immunities will, by constitutional decree, be defined and safeguarded from any attempts at official encroachment. This vital matter, one easily capable of sowing the seeds of major disaffection to the detriment of public tranquility and political stability, should no longer be left at the tender mercies of the leaders of government. The notorious habit, widely affected by the latter, of harrying oppositionists has been in the van of the elements that instigate intermittent outbursts of insurgency and rebellions in many of the emergent nations, including Nigeria. Lucian Pye has perceptively highlighted the element of the sinister and visceral phobia of governments-of-the-day for their opponents as one of the inflammatory fixities of the leadership scene in developing countries. He finds that "Opposition parties and aspiring elites tend to appear as revolutionary movements ${ }^{23}$ ".

But for this specific measure to be something more than a hollow gesture, the legislature must legislate and play more significant roles in policy-making. This is one promising way in which that organ will come to pull its weight as the fulorum of the efforts of the polity to manage its primordial, as well as its emerging, sources of conflicts. The custom whereby our Parliament used to sit for brief sessions between long intervals should be discarded in favour of a new rule that demands of its members that they work for about eight months in the year, at the least. This obligation will be spelled out in a provision of the Desiderative Constitution. And to create a fair number of significant platforms that will provide an adequate supply of roles with enough visibility and credibility to match the zest of restless ambitions in search of outlets, a two-chamber legislature will be stipulated for. To become law, every proposal will require the approval of the two houses; each house will be required to organize its work through committees, and each committee will bear the task of studying all proposed bills that fall within its subject-matter field and report them out to the full house for action. As already indicated, Prerogative powers will be abolished. Apart from the Con-

23 Ibid., p. 20. 
stitution itself as a possible source and depending on the case every action taken by the President must be bottomed on the mandate of a law enacted by the Legislature. This rule will ensure that the legislators have their hands full of work, so that in the process of dispatching their crowded agenda, they will, through constant practice and experience, master the techniques and skills of law-making after the fashion of latter-day Solons. This is an extremely important consideration. The pernicious tendency for the Executive and its appendage, the bureaucracy, to dominate the policy-making process as happened during the previous era, is a legacy which the departed colonial officialdom bequeathed to us, and which greatly needs to be given its unlamented quietus.

For under the colonialists' authoritarian system of government, there occurred a relatively differential rates of absorbtion of modern skills and capabilities as between the executive and legislative agencies. While bureaucratic activities were actively promoted and strengthened under the aegis of colonial officialdom, the legislative process tended to lag behind and to get only grudging support. The situation has remained largely unchanged till today ${ }^{24}$. The melancholy effect of this discrimination in favour of the bureaucratic sector has been the evident fact that, in Nigeria, for instance, we seem to be doing fairly well with managing affairs requiring for the most part the application of administrative solutions or for particularist decisions, whilst we fairly cripple along in matters needing the application of the critical skills for bargaining and accommodation of delicate socio-political issues or for universalist decisions. This situation demands immediate rectification. And it is a vital incentive underlying the principle of the Desiderative Constitution under which the legislature will have a dominant voice in the policymaking setting. Moreover, the law-makers, because they will be drawn from the different groups and walks of life in the body politic, will tend to reflect and represent the multitudes of significant interests and orientations, and, above all, their major debatable grounds as well. In the process of hammering out agreed-upon policies aimed at the solution of urgent socio-political questions, the legislators will be compelled to compare notes and experiences, among themselves, learn to syncretize the difference among the interests they represent and forge compromises, if they must achieve any meaningful aggregative functions. This is the concept of Palaver, the idea of talking until you agree. Sceptics who remember the screaming farce into which the pre-military era legislative process degenerated, may raise their eye-brows and grin at these exuberant imaginings brimming-over with optimism. The answer to such Doubting Thomases is that that legislative process never had a chance to settle down and work seriously at its grinding lesson in policy-making. The odds against it was long and formidable from start to finish. Probably, had circumstances been otherwise, it might have done much better than the record shows. At all events, short of installing an authoritarian regime that would rule by decree, backed by the expertise of the bureaucratic establishment, we do not seem to have much option except to decide to give future generation of legislators a chance to muddle their way through to a higher level of output capabilities.

24 For a general statement of this process and assessment of some of its consequences for the developing countries today, see Fred W. Riggs "Bureaucrats and Political Development" in Joseph La Palombara (ed) Bureaucracy and Political Development (1963), pp. 120-168. 


\section{Fight Against Corruption}

On equal fours with the pitfalls constituted by the institutional intransigence on the part of the primordial formations, and perhaps surpassing it in insidious influence, loom the furies of bribery, corruption, peculation and other forms of wrongdoing and abuses. We are all sufficiently and alarmingly aware that these cankers have eaten deeply into the social fabric. Quite a number of public officials, in both high and low places, have not scruppled to convert public funds placed under their trust to their private ends; others will not carry out their regular duties for which they are duly paid by the public without the inducement of palm-oil. It is readily conceded that these age-old vices are universal and show up in every society in the world. But this indisputable truism should not provide the subterfuge for unseemingly efforts to palliate their intrinsic vileness. For though their roots be innate in human nature, and though they rear up their horrid heads in every society, yet by common consent they are combatted with more or less systematic zeal and determination in almost every extant society. The goal is not the utopian one of extirpating their hydra-like existence, but the rather pragmatic one of abating them to levels each particular society considers consistent with the survival of a minimum degree of public decency within its body politic.

In our own case, it is not an unduly uncharitable and harsh judgement to assert that our public authorities have not met the pestilence with adequate energy and purposefulness. The tendency has been, in many cases, to administer a ridiculously mild rap on the knuckles of offenders, particularly if they are well-connected.

This virtual connivance with evil apart, there is another facet of the matter which should deeply distress all men of goodwill. This relates to the retributive and deterrent value of the sanctions imposed upon those who are unlucky or vulnerable enough to be brought to book. We believe that on both of these counts sentence of imprisonment which is most of ten the penalty meted out in such cases is not the most condign available. At best, imprisonment can impose temporary withdrawal of certain freedoms; and it has been alleged that it can also entail public odium und loss of social standing on the culprit. But for these suppositions to be valid, especially the myth about the shaming efficacy of incarceration, they must be shown to be in alignment with the actual norms and symbols of status and prestige existing in a given society. In our case, it is plain that, by this token, they are amiss and erroneous. The assumption that imprisonment is a blot on a person's escutcheon, makes him look declassé in the eyes of his fellows and, consequently is a major deterrence against anti-social conduct no longer carries conviction. The naked truth seems to be that in this day and age, in our society, at any rate, imprisonment is a blunderbuss that has spent its credibility and its sting to thrust home.

The form of anti-social acts with which we are here concerned stems essentially from a pattern of behaviour inspired by selfcentered norms. Its syndrome has been characterized as that of "self-orientation", which is the very antithesis of "collectivity-orientation". When its manifestation is rife and deep-rooted in a given society, the resulting atmosphere smacks of the developmental sequence we have denominated "incorporative dualism", when the orientation of individuals 
and groups in the society have not developed firm and secure roots in national commitments and identifications ${ }^{25}$. This is not so much a case of an individual or individuals preferring the interests of the groupings they are affiliated with - whether associational or communal - as it is that of an individual seeking to advance his illicit egotistical interests through jobbing his public trust. When the matter is examined more closely, it will come to light that those who practice these evils ostensibly, as is usually thought in the interests of their ethnic or linguistic kins, are merely posturing and using this handy pretext as a stalking horse for their ulterior individualistic purposes. This conjecture is easily seconded by the incontestable fact that, not seldom, a kin of the grafter falls a victim of his illegal ransom.

Certain of these facts, the Desiderative Constitution will deal with the matter by a direct, head-on route. Because the efficient cause of such venal behaviours is invariably the inordinate lust for filthy lucre, the problem will be tackled mainly from that side.

In other works, its quiding principle in this thicket of criminology will be simply that those whe have acquired illegal booty, one way or another, should be made to disgorge it with interest. Accordingly, an explicit provision of the basic law will lay down that fines proportioned to the value of the offence will be the mandatory punishment in all convictions for bribery or embezzlement. The option of imprisonment will be expunged because it now carries no onus of social stigma. And, in any case, why should the society spend its money to feed, clothe and house those whe have cheated it out of its property and its moral claims on their honest discharge of their offices. The thrust of societal indignation is likely to go home when the offenders are compelled to forgo the opportunity of enjoying their ill-gotten gains for the gratification of which, as it is to be expected, their cupidity compels them to set pre-eminent store, by, and to feel most deeply when they are compelled to forgo them.

Thus the conception of an adequate system of deterrence to be incorporated in the criminal code under the Desiderative Constitution will veer in the direction of subsuming all those familiar forms of official misconduct under the category of pecuniary felony. And to facilitate quick trial of such cases, a network of special courts, to be called "Court of Special Jurisdiction" will be established throughout the country, on the model of the existing Federal Revenue Courts. The competence of these courts, which will be set up and organized under the federal jurisdiction, will include offences against both federal and state interests.

Pressure of time and space does not permit a complete presentation of the outline of the Desiderative Constitution and some of its basic features have not been treated. Nonetheless, the much that have been unfolded indicates hopefully clearly the essential directions of its approach to institution-building, the sources of its logical thrust and broad nature of the empirical linkages of the theoritical premises it incorporates into its structuring criteria. It aims at prescribing a fundamental blueprint of the polity whose major institutions are intended as structural embodiments of certain demonstrated needs of our society as it gropes towards the development goal of modernization. These needs have become so crucial and

25 H. V. Wiseman, Political Systems (1967), pp. 18-19. This behavioural norm, he argues, is vital in relation to integration and exist peculiarly, though not solely, in "new nations". 
ominous that actions to solve them are justly considered the desiderata in achieving our hope of developing the minimum conditions precedent of achieving a stable and progressive evolution toward higher forms of national unity and integration. To attain this supreme goal the Desiderative Constitution utilizes the approach of attempting to institute formal structures and processes whose ensemble will produce a system of forces locked in a pull-push contest with the spawn of primordialism. It has, furthermore, an heuristic use, since any one picking up a copy of it can by himself readily pick out those areas of need we consider to be of cardinal import to our national aspirations. The structure of the Desiderative Constitution as here delineated may be low on orthodoxy, but certainly not empiricism and logical rigor. 
The Emergence of Competitive Party Systems: Comparative Observations on the Custodial Party Period in the United States, Sri Lanka and Canada

\author{
By Calvin A. Woodward
}

The article introduces the notion of a custodial party system to refer to the one party dominant party systems which usually characterize an initial period of postindependence politics in new states. The tendency of custodial party systems has been to give way to military or one party rule once internal management problems in the custodial party become intense and when national unity and government efficiency become seriously impaired. The emergence of competitive party systems from custodial party backgrounds has been rare. Three cases where this has occurred are Sri Lanka, Canada and the United States; national competitive party systems having emerged respectively in 1956, 1896 and 1800.

The paper examines comparatively the custodial party period in these cases and focuses on the generation of parties, the means employed by custodial parties to mobilize popular and governing majorities, the break-down of custodial parties and their eventual turn-over by opposition parties. The paper finds that politica! techniques used by custodial parties served to ensure governmental stability and national unity during the early years after statehood was achieved, but that the rule of custodial parties caused a reaction to centralization and aroused centrifugal tendencies nationally. In these cases, opposition parties, which electorally were organizational pioneers, harnessed potential separatist forces and formed them into a national majority conducive to both government and national stability. The emergence of a competitive party system in Canada, the United States and Sri Lanka, therefore, was induced by and moderated disunifying manifestations which in most new states have tended to rationalize the abortion of democratic party systems.

\title{
The Desiderative Constitution: A Tentative Outline of a Theory
}

Ву С. Ево

The developing polities are viewed as societies experiencing tension caused by the juxtaposition of sets of primordial structures and values and those typical of industrial societies. The mix of these two incongrous elements often results in a behavioural pattern in which a noticeable gap appears to exist between formally prescribed norms of conduct on the one hand, and actual behaviours, on the other. This highly unstable and volatile co-existence is perceived as one of the basic sources of the chronic crises that have become a conspicuous feature of transitional societies. In this regard, the brief history of Western-style parliamentarism in Nigeria between 1960-1967 provides one with a striking object lesson. Thus, the epochal task facing the developing societies would seem to oblige them to devise ways of achieving a peaceful evolution in the direction of increasing modernity that will allow them to pursue the twin goals of nationhood and rapid social and economic progress unhampered by series of cries and disruptions. This path of advance is visualised as leading from the present stage of "Incorporative dualism“, 
where the growth of formal, foreign system of norms and values are subverted and retarded by premordial types, to that of "Fusional dualism" where the formal elements will begin to gain the upper hand in influencing actual behaviour. One strategy which this essay considers as a highly plausible approach toward this objective is identified under the concept of the "Desiderative Constitution", which is formulated as a codification of formal definitions of institutions and norms explicitly designed to engender orientations whose net effects will tend to curb those manifestations of tradition that exert a dysfunctional impact on the emergence of modernizing forces while at the same time reinforcing and striking deep roots in the benign hereditary milieu.

\section{The Political Image of Ghanaian Civil Servants}

\section{By Rolf Hanisch}

In African countries, the civil service represents a social class of considerable importance which surpasses by far its numerical strength. The success of the Politicians' policy depends largely on its efficiency and its subjective consciousness of wanting to prepare and implement a certain policy. In the context of their societies, the civil servants represent most of ten a socially privileged group, which has considerable group interests to defend and which has, therefore, the reputation of being not particularly innovatory in their attitude.

This paper tries to gather some empirical data on the political image of civil servants in Ghana on the basis of 237 questionnaires. The core of the series of problems concerned were the economic and development problems and prospects of the country under particular consideration of international relations. If this sample is representative, the approval and, thus, support of radical solutions in whatever direction - is hardly to be expected from the majority of the Ghanaian civil service. It sticks much more to the prevailing structures, tries to come to terms with them, to intensify and improve them and to expand them positively for Ghana. The world image is often rather ingenious and the solutions suggested for acknowledged problems are rarely ingenious and reasoned. This is moreover obviously based on a considerable over-assessment of the importance and possibilities of Ghana in the world.

\section{Mexico's Establishing of the Exclusive Economic Zone to its Coasts}

\section{By Gerhard Scheffler}

From the beginning, Mexico was one of the first states claiming the exclusive economic zone. The setting up of this zone by Mexico in July 31, 1976 remains in the recent development of this matter: One month after US-President Harry S. Truman's Proclamation on the continental shelf Mexico claimed the shelf before its coasts. In 1972 the Afro-Asiatic countries demanded the body of sea, therein coastal state would have special jurisdiction to explore and exploit for its own benefit the marine resources and those of the seabed and subsoil of the 